\title{
An emerging EU energy diplomacy? Discursive shifts, enduring practices
}

Citation for published version (APA):

Herranz-Surrallés, A. (2016). An emerging EU energy diplomacy? Discursive shifts, enduring practices. Journal of European Public Policy, 23(9), 1386-1405. https://doi.org/10.1080/13501763.2015.1083044

Document status and date:

Published: 01/10/2016

DOI:

10.1080/13501763.2015.1083044

Document Version:

Publisher's PDF, also known as Version of record

Document license:

Taverne

Please check the document version of this publication:

- A submitted manuscript is the version of the article upon submission and before peer-review. There can be important differences between the submitted version and the official published version of record.

People interested in the research are advised to contact the author for the final version of the publication, or visit the DOI to the publisher's website.

- The final author version and the galley proof are versions of the publication after peer review.

- The final published version features the final layout of the paper including the volume, issue and page numbers.

Link to publication

\footnotetext{
General rights rights.

- You may freely distribute the URL identifying the publication in the public portal. please follow below link for the End User Agreement:

www.umlib.nl/taverne-license

Take down policy

If you believe that this document breaches copyright please contact us at:

repository@maastrichtuniversity.nl

providing details and we will investigate your claim.
}

Copyright and moral rights for the publications made accessible in the public portal are retained by the authors and/or other copyright owners and it is a condition of accessing publications that users recognise and abide by the legal requirements associated with these

- Users may download and print one copy of any publication from the public portal for the purpose of private study or research.

- You may not further distribute the material or use it for any profit-making activity or commercial gain

If the publication is distributed under the terms of Article $25 \mathrm{fa}$ of the Dutch Copyright Act, indicated by the "Taverne" license above, 


\section{Journal of European Public Policy}

\section{An emerging EU energy diplomacy? Discursive shifts, enduring practices}

\section{Anna Herranz-Surrallés}

To cite this article: Anna Herranz-Surrallés (2016) An emerging EU energy diplomacy? Discursive shifts, enduring practices, Journal of European Public Policy, 23:9, 1386-1405, DOI: 10.1080/13501763.2015.1083044

To link to this article: https://doi.org/10.1080/13501763.2015.1083044

Published online: 23 Sep 2015.

Submit your article to this journal $\pi$

Џll Article views: 2569

Q View related articles ๘

View Crossmark data

4 Citing articles: 31 View citing articles 둔 


\title{
An emerging EU energy diplomacy? Discursive shifts, enduring practices
}

\section{Anna Herranz-Surrallés}

\begin{abstract}
The European Union's (EU) external energy policy has been steadily taking shape since the mid-2000s. EU authorities appear to have even taken on functions that could be classified as 'energy diplomacy', i.e., the use of foreign policy means to secure access to foreign energy supplies. With the aim of gauging and accounting for these developments, this article undertakes a double analytical move, one conceptual and one theoretical. Conceptually, it distinguishes between energy governance and energy diplomacy as tools for better comprehending the type and scope of policy change. Theoretically, it draws on discursive institutionalism to examine how and why policies change (or endure) by looking at the role of ideas in two dimensions of social action that are not often analysed side by side: policy discourses and policy practices. The article illustrates the practical relevance of this distinction through empirically examining the EU's promotion of diversification of natural gas supplies.
\end{abstract}

KEY WORDS Energy policy; EU external relations; discursive institutionalism diplomacy; governance; practices.

\section{INTRODUCTION}

The term energy diplomacy has been used in the scholarly literature to refer to the various forms of state power used to secure access to foreign energy supplies, and to promote government-to-government co-operation in the energy sector (Goldthau 2010: 25). This notion, often used to describe the close intermeshing of foreign policy and energy policy in cases such as China, Russia or the United States, has been rarely used in connection to the European Union (EU). This may not be surprising given that energy policy is one of the areas that has been most resistant to European integration, particularly when it comes to security of supply (Buchan 2009: 79ff). Moreover, EU energy policy was designed around a liberal model in which energy supplies were approached as 'a matter for private companies rather than government command' (Youngs 2011: 51). Consequently, also in its external energy relations, the EU typically aimed to create a common regulatory space with other regions (Prange-Gstöhl 2009), rather than directly involving itself in pursuing bilateral energy deals or infrastructure projects. In scholarly terms, EU external energy policy has thus been 
conceptualized as external energy governance (Lavenex 2004; Padgett 2009), rather than energy diplomacy.

However, since the late 2000s the EU has progressively taken on a broader role in external energy relations in a way that departs from the traditional instruments of external energy governance. One of the most glaring expressions of this is the EU's direct involvement in promoting external infrastructure projects to diversify gas supply routes such as the multi-pipeline concept of the Southern Corridor. However, the scholarly interpretation of these recent developments has been diverse. In terms of policy substance, some have regarded the EU's assumption of a more geopolitical stance as a sign of the gradual erosion of its market-liberal energy paradigm (Kuzemko 2014). Conversely, others have argued that EU external energy policy is firmly rooted in ideas and the instruments of liberal energy governance (Abbasov 2014). Similarly, in terms of the degree of integration, for some authors the recent changes reflect a process of 'incremental Europeanization of key dimensions of energy security' (Youngs 2011: 41), while for others energy security is expected to remain a 'low-Europeanization policy space' (Escribano et al. 2011: 213).

In view of this diversity of interpretations, this article aims to assess to what extent the EU is taking on the functions of energy diplomacy and, if so, to contribute to explaining those developments. To that aim, the article advances the conceptual distinction between energy diplomacy and energy governance as a tool for better comprehending the degree of policy change undergoing EU external energy policy. Theoretically, it builds on discursive institutionalism (Schmidt 2008, 2010) to examine how and why policies change (or endure) by looking at the role of ideas in two dimensions of social action that are not often analysed side by side: policy discourses and policy practices (cf. Neumann 2002). Empirically, the article examines EU debates on energy security since the early 2000s as well as the implementation of new instruments to promote the diversification of gas supplies. Through this bi-dimensional approach, this article argues that external energy policy is undergoing a layered policy shift characterized by a marked change in the overarching terms of policy discourse and substantial policy innovation, but notable continuity at the level of policy practices. While the assessment of the results of the EU's external diversification efforts is beyond the scope of this article, the analysis suggests that the particular mixture of energy governance and energy diplomacy emerging in this policy field is, for better or for worse, part of the explanation for its moot success.

This article is structured as follows. The first section spells out the distinction between energy governance and energy diplomacy, and discusses the limitations in the existing literature on the topic. The second section presents the theoretical approach. The third and fourth sections set out the empirical analysis addressing, in turn, the evolution of the EU policy discourse on energy security and the policy practices underpinning new external diversification instruments. The final section concludes by discussing the practical 
implications of the EU's particular 'third way' of conducting external energy relations, as well as the theoretical implications for studying policy change.

\section{ENERGY GOVERNANCE AND ENERGY DIPLOMACY: TOWARDS A 'PARADIGM SHIFT' IN EU EXTERNAL ENERGY POLICY?}

This section aims to set the parameters to assess whether the EU is taking on functions of energy diplomacy, and to gauge the significance of any change compared to the previous policy, here characterized as (external) energy governance. A useful analytical tool for this conceptualization is the classical notion of policy paradigm, understood as 'a framework of ideas and standards that specifies not only the goals of policy and kind of instruments that can be used to attain them, but also the very nature of the problems they are meant to be addressing' (Hall 1993: 279, emphases added). This section discusses energy governance and energy diplomacy as modes of external relations emerging from different energy policy paradigms (see Table 1). While these modes are taken here as ideal types, acknowledging that elements of both have long been present in Europe, this section argues that recent developments seem to be changing the established 'policy mix', and the division of labour between the EU and its member states.

Seen from a paradigmatic lens, EU energy policy typically has been described as following a market paradigm. The gradual involvement of EU institutions in energy matters since the early 1990s has been related to the ascending neoliberal ideas informing the Single Market Programme, which gave a new boost to competition policy and the idea of a 'regulatory state' at the EU level (McGowan 1989: 547). More recently, the second and third 'energy packages' (2003 and 2009 respectively) were also boosted by the revitalization of the 2000 Lisbon Agenda, which placed 'consumer sovereignty' at the core of the EU idea of societal welfare (Eikeland 2011: 257). EU energy policy was thus born with the main goal of eliminating the barriers to free and fair competition in the energy markets. The idea of energy security underpinning this policy goal is that a liberalized and de-monopolized energy sector is the best guarantee for efficient and reliable supplies. The problem is therefore not energy dependence per se, but the lack of a well-functioning market regulatory regime with producing and transit countries. In its external energy policy, the EU has thus sought to bring third countries closer to its energy governance standards via a variety of instruments, ranging from full-blown institutions such as the Energy Community, to the support of trans-governmental exchanges via frameworks such as the Euro-Mediterranean Association of Regulators. Therefore, EU external energy policy has been described as a form of external governance, namely the extension of the Union's acquis communautaire beyond the member states (Lavenex 2004: 681).

The characterization of the EU energy policy paradigm becomes certainly more difficult when adding the member states to the analysis. Being a shared 
Table 1 Conceptualization of external energy governance and energy diplomacy

\begin{tabular}{|c|c|c|}
\hline & Energy governance & Energy diplomacy \\
\hline Problem definition & $\begin{array}{l}\text { Energy security as an } \\
\text { economic problem } \\
\text { Lack of transparency and } \\
\text { regulatory gaps; market } \\
\text { failures }\end{array}$ & $\begin{array}{l}\text { Energy security as a } \\
\text { (geo)political problem } \\
\text { Over-reliance on markets; } \\
\text { lack of strategic vision }\end{array}$ \\
\hline Policy goals & $\begin{array}{l}\text { Promote economic } \\
\text { competitiveness; defend } \\
\text { consumer sovereignty } \\
\text { Ensure energy supplies } \\
\text { through guaranteeing } \\
\text { highly functional energy } \\
\text { markets }\end{array}$ & $\begin{array}{l}\text { Promote national interest; } \\
\text { defend political } \\
\text { sovereignty (unity/ } \\
\text { solidarity, in international } \\
\text { institutions or alliances) } \\
\text { Ensure energy supplies } \\
\text { through strategic } \\
\text { diversification and } \\
\text { maintaining political trust } \\
\text { with foreign suppliers }\end{array}$ \\
\hline Policy instruments & $\begin{array}{l}\text { Multilateral institutions and } \\
\text { frameworks to promote } \\
\text { regulatory harmonization } \\
\text { (Dis)incentives to induce } \\
\text { third countries to adopt } \\
\text { liberal market energy } \\
\text { reforms }\end{array}$ & $\begin{array}{l}\text { Bilateral intergovernmental } \\
\text { agreements (IGAs) in } \\
\text { energy based on particular } \\
\text { terms } \\
\text { Political, legal, and } \\
\text { economic tools to back } \\
\text { strategic energy } \\
\text { infrastructure projects or } \\
\text { commercial agreements }\end{array}$ \\
\hline Policy competences & $\begin{array}{l}\text { Regulators, trans- } \\
\text { governmental networks, } \\
\text { energy companies, and } \\
\text { public authorities (mainly } \\
\text { from economic and energy } \\
\text { sectoral departments) }\end{array}$ & $\begin{array}{l}\text { Public authorities (including } \\
\text { high-level political } \\
\text { representatives and } \\
\text { foreign affairs officials); } \\
\text { energy companies (often } \\
\text { state-owned) }\end{array}$ \\
\hline
\end{tabular}

Note: For a similar analytical choice complementing the policy elements of Hall's (1993: 279) definition of policy paradigm with a fourth category to capture the institutional expression of the paradigm, see Kern et al. (2014).

competence, the member states keep core prerogatives, among others, determining the sources and structure of their energy supplies (Art. 194.2 TFEU). While the European Commission and some likeminded states have pressed for EU-level market solutions, other member states have adhered to a public control paradigm, which emphasizes the strategic character of energy and the idea that state intervention is needed to meet 'public obligations' such as security of supply (McGowan 1989: 547). From this perspective, energy dependence needs to be addressed as a potential (geo)political problem. The goals of defending national economic interest and political autonomy have justified the protection of energy companies (the so-called national 
champions) and the instruments of energy diplomacy, such as the political flanking of long-term bilateral agreements with producing countries (Youngs 2011: 49ff). To a greater or lesser extent, therefore, national energy diplomacy has also been a defining trait of external energy relations in and beyond Europe.

However, EU external energy policy has been changing quickly in the last few years. In the context of growing energy dependence and deterioration in political relations with Russia, experts have noted that new 'geopolitical ideas' have been on the rise among European policy-makers (Kuzemko 2014: 64ff), while “'market purists" are in full retreat' (Youngs 2011: 54). ${ }^{1}$ In this light, the Nabucco pipeline has been regarded as 'a clear political rather than a purely commercial undertaking' (Ibid.: 55; Baev and Overland 2010) and some of the policy initiatives aimed at giving an edge to this EU flagship project could be easily classified as instances of EU-level energy diplomacy. How, then, to gauge and account for these developments? As the remainder of this section spells out, most frequent theoretical approaches employed in examining EU external energy policy have so far not provided a clear answer.

On one hand, intergovernmentalist and institutionalist approaches have generally neglected the possibility of an emerging EU-level energy diplomacy, albeit for different reasons. Studies inspired in intergovernmentalist premises have typically stressed the lack of integration in EU external energy policy against the backdrop of persistent divisions between its member states, which are in turn the result of relatively immutable factors such as size, geography, energy mix, degree of energy dependence or longestablished political relations with foreign suppliers (Baumann and Simmerl 2011; Schmidt-Felzmann 2011). In turn, institutionalist studies have seen more room for the development of an EU external energy policy, but mostly along the lines of external energy governance. That is to say, these approaches have focused on internal-external path dependencies in the sense that the development of the internal energy market generates pressures to extend these rules abroad (Lavenex 2004; Mayer 2008).

On the other hand, geo-economic and constructivist perspectives have found less change towards EU energy diplomacy than we would expect from the changing material or discursive contexts respectively. Geo-economic perspectives predict a clearer shift towards a so-called 'regions and empires' scenario (Correlijé and Van der Linde 2006). That is, the tightening of global energy markets during the 2000s and the resulting reinforcement of the position of producer countries are factors that are considered to demand bolder intervention by the EU in energy security matters than is actually the case in practice (Umbach 2010). Similarly, constructivist analyses, drawing mostly on securitization theory, have described the growing tendency to frame energy dependency as a geopolitical risk, but have not found full securitization dynamics leading to the fast adoption of exceptional measures at EU level (McGowan 2011; Natorski and Herranz-Surrallés 2008). 
Finally, recent studies examining the EU and/or member states' energy policies directly through the prism of policy paradigms provide a mixed picture. Whereas most studies concur in diagnosing the erosion of marketliberal ideas, they offer different interpretations as to the degree and nature of the change. For example, Helm (2005) claimed that a 'paradigm shift' had taken place in many corners of the globe, but that the actual policy consequences had not yet materialized. Kern et al. (2014) also identify a paradigm change in energy policy in the United Kingdom, even though towards a less coherent one. Recent studies on EU external energy policy in this journal have also pointed out growing complexity, but reaching partially different conclusions. While Kuzemko (2014) finds a multiplication of policy narratives challenging the market-liberal one, Goldthau and Sitter (2014) find a growing mix of 'liberal' and 'illiberal' instruments, but predominance of the liberal goals. Building on these studies, the next section argues that constructivist variants of institutionalism can be further fine-tuned to unravel this complexity and account for it.

\section{ANALYSING POLICY CHANGE (AND CONTINUITY): DISCOURSE AND PRACTICE THROUGH DISCURSIVE INSTITUTIONALISM}

The literature on policy paradigms emerged in the late 1980s with a trend that sought to emphasize 'the influence of ideas, general precepts and representations', which had generally been neglected in policy analysis (Surel 2000: 495-6). The focus on ideas and discourse was also furthered within the institutionalist tradition as a way to overcome the difficulties of newinstitutionalist orthodoxy to cope with policy change, given its focus on institutions as exogenous constraints on policy actors (Béland 2009; Hay 2006; Schmidt 2008). These new approaches emphasizing ideas and discourse focused instead on institutions as internalized structures by policy actors. As stated by Hay (2006: 65) 'it is not just institutions, but the very ideas on which they are predicated and which inform their design and development, that exert constraints on political autonomy'. However, these approaches have not fleshed out the consequences of this conception of internalized ideational structures. As argued below, the notion of practices can help enrich the institutionalist debate, by looking not only at the representation of ideas in policy discourses, but also the ideas underlying policy practices.

Within the constructivist institutionalist approaches, discursive institutionalism (DI), as conceptualized by Vivien Schmidt (2008, 2010), provides an interesting basis to further conceptualize the role of ideas in discourses and practices. In Schmidt's formulation, policy change and continuity can be explained by the interplay of the actors' foreground discursive abilities and background ideational abilities. Foreground discursive abilities are defined as the 'logic of communication, which enables agents to think, speak, and act outside their institutions even as they are inside them... 
and to persuade one another to change those institutions or to maintain them' (Schmidt 2008: 314). It is therefore through discourse, understood as 'an interactive process of conveying ideas' (Ibid.: 303), that institutions may always be subject to change. In turn, background ideational abilities stand for the deep-seated knowledge and worldviews that enable actors to make sense of their context. As mentioned by Schmidt, this notion comes closer to Bourdieu's theory of practice concepts of habitus, or an actors' disposition to act in a certain manner (Schmidt 2010: 14), which is in turn influenced by the doxa, or taken-for-granted assumptions, beliefs, or opinions that prevail in a given time and field (Schmidt 2008: 316). Therefore, in contrast to the foreground dimension, where policies and institutions are routinely re-assessed through discourse, this background dimension is often left unarticulated and undiscussed, and hence is less subject to change.

DI studies have paid particular attention to the foreground discursive dimension. Similar to other discursive approaches, DI focuses on explaining why some ideas are more successful in gathering support than others. The first factor is the substance of ideas. Inspired by deliberation theory, DI assumes that persuasive ideas are those that combine sound arguments in $\operatorname{cog}$ nitive terms (i.e., those justifiable from the point of view of the problem to be solved) and in normative terms (i.e., those appropriate and/or legitimate within the context of the values and aspirations of the public) (Schmidt 2008: 313). Secondly, DI also posits that the context within which discursive interaction takes place is relevant for the dynamics of persuasion. More specifically, it has been suggested that within communicative discourse (communication between policy-makers and the wider public), normative arguments tend to be more pronounced and relevant for persuasion than in $c o-$ ordinative discourse (among policy-makers and experts), where discursive interaction often concentrates on factual and technical arguments (Herranz-Surrallés 2012; Kangas et al. 2014; Schmidt 2008). The importance of including the communicative discourse in the analysis ties well with Hall's observation that third order changes, those affecting not only the instruments of a policy but also its goals, cannot be confined to the boundaries of the policy network dealing with a specific issue, but require a broader political and societal debate (Hall 1993: 287ff).

The background ideational dimension needs further elaboration, as DI studies have not yet tapped into the analytical potential implied in this notion. One of the approaches to investigate the taken-for-granted ways of thinking and acting in a particular policy field is the focus on practices, as recent literature in political science and international relations has proposed (Neumann 2002; Adler and Pouillot 2013; Bueger and Gadinger 2014). In Bourdieusian terms, practices are both individually and socially determined, as they emerge from actors' habitus, but this is embedded in the doxa that regulates a given field of social action. It is this social dimension that makes practices particularly prone to reproduction, as 'the need to engage one another forces people to return to common structures' (Swindler, in Neumann 2002: 631). Practices also tend to stability because they are the 
expression of the power relations in a field, meaning that 'actions to innovate will be met with counter-actions to resist change and hold intact the existing set of preconditions for practice' (Neumann 2002: 641). Therefore, an analysis of policy change also needs to take into account how new policy ideas are incorporated into existing practices, and how much resistance they encounter from key actors in the field. Institutionalist theorizing has actually paid growing attention to practices, claiming that gradual change can only be captured 'if we can distinguish analytically between the rules and their implementation or "enactment" (Streek and Thelen 2004: 13). However, in these studies, the daily enactment of the rules is considered a crucial source of change, a creative act that enables institutional transformation. Yet, according to DI and practice theorists, the enactment of rules can also embody the resistance to institutional innovation by the actors on the ground, and thus become a source of policy continuity.

In order to implement the above-mentioned two-dimensional analytical framework, this article proceeds to examine, first, the evolution of policy discourse (the foreground dimension) on EU external energy policy since the early 2000s. The section uses the described categories of energy governance and energy diplomacy as analytical benchmarks to identify discursive continuities and changes in the communicative and co-ordinative discourse. Owing to the highly composite character of the $\mathrm{EU}$, its communicative discourse is usually very thin and dispersed (Schmidt 2006: 262-3). One of the few sources for tracing EU-level political communication is the European Parliament. Although the Parliament has little decision-making powers in this area (many aspects of EU external energy policy are non-legislative), plenary debates are a good indicator for how representatives of the Commission (sometimes also the Council) and members of the European Parliament (MEPs), many of them belonging to governing parties in their respective countries, publically defend alternative policy choices before an EU-wide audience. Parliamentary debates are examined through a detailed content analysis (see Table 1 and online supplemental material). Regarding co-ordinative discourse, the analysis draws mainly on preparatory documents in the Council and Commission, the two crucial institutions involved in EU external energy policy decision-making. Particular attention is placed on the normative justification of policy ideas as these are, according to DI, a necessary element for advancing new policy ideas, particularly in the communicative sphere.

The second section focuses on practices in the policy field (the background dimension). The study examines the implementation of new policy measures to support external diversification as a 'most likely case'. In other words, if the EU is indeed performing energy diplomacy, it should be observable in this specific area of external energy policy. The analysis looks at what officials and practitioners directly involved in the implementation of this policy do and how they justify what they do, with the aim to capture the role of actors' dispositions, the accepted rules of 
the game, and any resistance to change in established practices. The same policy elements of energy governance and energy diplomacy are used as benchmarks to examine which mode predominates in the enactment of the new policy measures. This part of the analysis is based on documents from the policy process as well as eight confidential interviews with officials from the European Commission and the European External Action Service (EEAS), member states' and third-country diplomats, and representatives from the energy business sector, conducted between April 2012 and May 2014, in Brussels, London and Barcelona.

\section{CHANGE IN THE FOREGROUND: EMBRACING THE ENERGY DIPLOMACY DISCOURSE}

This section traces the EU policy discourse on energy security since the year 2000 , when in a context of volatility and upward trend in oil prices, the Commission published its first green paper on the security of energy supply. The Commission proposed, among others, new directives on the security of oil and gas supplies. However, the idea of higher EU intervention in this area was met with scepticism among the member states, and particularly the European Parliament, which in 2003 categorically rebuffed the Commission's proposed directives, arguing that security of supply was both a national prerogative and the responsibility of energy companies (European Parliament 2003). The debates on energy security at the European Parliament $(2001,2003)$ are exemplary of the predominance of external energy governance ideas (see Figure 1). The instruments proposed to deal with energy dependency were, internally, further liberalization of the energy sector and demand-side measures (see online supplemental material) and, externally, the promotion of market rules in producer and transit countries. Energy dependency was overall approached as an economic and/or environmental problem, and an area with a low risk of supply disruptions. As bluntly stated by an MEP:

Perhaps we would have something different to say if supplies really had been interrupted; we would probably be in a state of shock and attacking the Commission, asking why it had not responded to a crisis situation of this kind. The only thing is that I see such a situation as highly unlikely. (Linkohr, in the European Parliament 2003)

The 'shock' came less than three years later with the gas supply interruption of January 2006, following a political-commercial dispute between Russia and Ukraine. This episode, however, triggered a different reaction in the Council/Commission and the Parliament. Discussions in the Council revealed strong resistance to addressing security of supply matters at the EU level. Many national contributions in preparation for the European Council of March 2006 emphasized the principles of sovereignty and freedom of choice regarding national energy mixes, and resisted the idea of linking up energy and EU foreign policy considerations. Likewise, the 


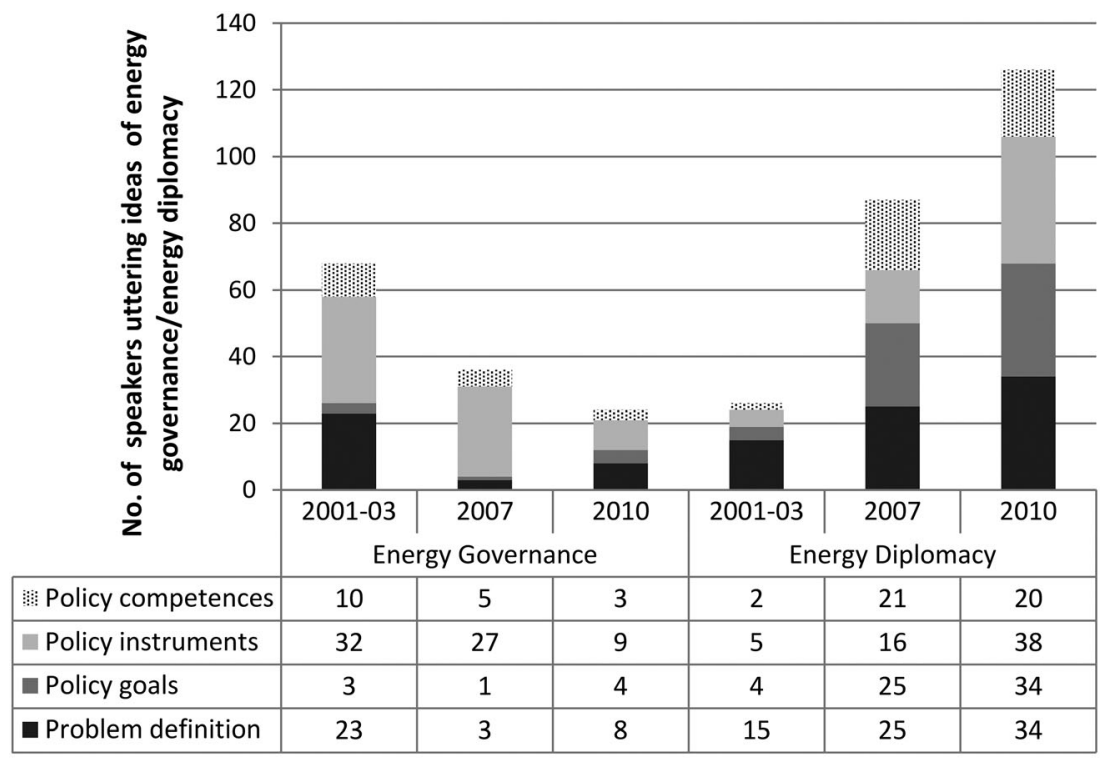

\section{Selected Parliamentary Debates}

Figure 1 Evolution of the policy discourse at the European Parliament Source: The author's analysis of the European Parliament's data (2001, 2003, 2007, 2010).

Note: The data have been manually coded using the software Atlas.ti. Each policy element encompasses two/three sub-codes (see online supplemental material). For comparability purposes, the parliamentary debates of 2001 and 2003 are aggregated in this graph, but the data are provided separately in the online supplemental material. The number of participants in each debate is 34 (2001 and 2003), 36 (2007), and 56 (2010).

aim of diversification, which was prominent in early drafts of the Presidency's conclusions, including direct references to the Nabucco pipeline (Council of the EU 2006a: 2), even disappeared in later versions, and was replaced by a reference to relations with Russia as a key priority (Council of the EU 2006b: 4). At the same time, instruments of external governance gained prominence, with the final document calling for 'developing a strategy for exporting the internal energy market approach to neighbouring countries' (European Council 2006: 17). The Commission and High Representative called for a 'foreign energy policy' in a landmark joint document (European Commission, SG/HR 2006: 1), which recognized, however, 'the legitimate right of individual Member States to pursue their own external energy relations for ensuring security of energy supplies' (Ibid.).

In contrast, at the European Parliament the short stoppage of gas supplies in January 2006 was widely deemed an event exposing the weaknesses in EU energy policy. The 2007 debate on energy security reflects a turn toward ideas for energy diplomacy regarding the problem definition, policy goals 
and the need to grant the EU higher competence in energy security and better integrate energy into EU foreign policy. This debate also signifies the growing use of normative arguments, particularly in framing the policy goals. Most notably, the reference to solidarity emerged in spectacular fashion compared to previous debates. For example, nearly half of the 36 MEPs who took part in the debate explicitly referred to the goal of solidarity among member states, both in reference to mutual assistance in the event of supply crises and, more generally, as a duty to work for a common EU interest in their relations with suppliers. When it came to policy instruments, however, many MEPs continued to insist on the internal liberalization and the promotion of market rules abroad (see Figure 1).

Some EU member states, particularly Poland, also turned to energy diplomacy ideas, proposing the inclusion of the principle of energy solidarity into the Treaty of Lisbon. Although this idea was rejected by several member states (Natorski and Herranz-Surrallés 2008: 81), it has been argued that one of the reasons why the then German EU Presidency gave in to Polish demands was that 'the inclusion of solidarity clauses tied in well with the perceived need to make the treaty more relevant to European publics' (Roth 2011: 621). From this moment, the idea of solidarity became a mandatory feature within subsequent documents on security of supply and external energy relations. The so-called Second Strategic Energy Review published by the Commission in November 2008 even came to be titled, 'An EU Energy Security and Solidarity Action Plan'.

Discussions on external diversification intensified after the unprecedented gas disruption of January 2009. The then Czech EU Presidency called on the Council to be more proactive in external energy policy and organized a series of high-level conferences to boost the Nabucco project. However, the coordinative discourse remained divided. Several member states, most notably Germany and Austria, refused to consider Nabucco as a 'strategic project' unless other proposed pipelines, including the Russian-sponsored Nord Stream and South Stream, were considered to be on equal terms (Socor 2009). In contrast, the episode further reinforced the discursive shift within the European Parliament, where now also the instruments suggested by most MEPs pertained to the category of energy diplomacy (see Figure 1), such as the EU's direct involvement in promoting diversification away from Russia. The Commission also progressively abandoned its initially neutral position and started to openly criticize member states' support for alternative pipelines such as the South Stream, which would make the EU 'unnecessarily dependent on the Russia trading system' and 'which are not in the European interest' (Oettinger, in European Parliament 2010).

Although some member states continued to maintain an ambiguous stance regarding the Southern Corridor, it is noticeable that support for direct access to Caspian gas was progressively accepted as common ground at the same time as the South Stream disappeared from the Council's public documents. In February 2011, the European Council invited 
the Commission to 'continue its efforts to facilitate the development of strategic corridors for the transport of large volumes of gas such as the Southern Corridor' (European Council 2011), giving a green light for certain policy innovation. For instance, the European Council embraced the view that it would be possible to grant funding to projects 'justified from a security of supply/solidarity perspective, but unable to attract enough market-based finance' (Ibid.). It also invited the Commission to prepare a proposal for introducing greater transparency into the highly sensitive domain of the energy intergovernmental agreements (IGAs). Several months later, it authorized the Commission to negotiate a legal framework for the TransCaspian Pipeline with Azerbaijan and Turkmenistan on behalf of the member states, giving the Commission its first mandate to negotiate a segment of external energy infrastructure. In summary, by the end of the decade there had been a shift in the overarching terms of policy discourse, particularly as seen in communicative discourse, but also in the co-ordinative sphere, where the Council eventually endorsed new policy ideas in EUlevel energy diplomacy.

\section{CONTINUITY IN THE BACKGROUND: THE RESILIENCE OF EXTERNAL ENERGY GOVERNANCE AND NATIONAL ENERGY DIPLOMACY}

This section analyses practices, focusing on crucial actors involved in implementing the above-mentioned new measures to support external diversification. The first sub-section deals with how the officials responsible for implementation, particularly within the European Commission, enacted the new instruments. The second examines the practices favoured by the other key actors in the field: energy companies and governments.

\section{The Commission's practices: energy diplomacy through external energy governance}

As seen in the previous section, the European Commission was eventually one of the actors more assertively playing into the discourse of energy diplomacy. When it comes to actual practices, however, the Commission acted more in line with its established role as the defendant of the internal energy market and the external promotion of the acquis. This can be seen, first, in the Commission's enduring disposition to frame energy diplomacy instruments within the goals of energy governance. Commission officials have tried to maintain an 'at arm's length' approach, justifying the support for diversification measures as actions against 'market failures' (Devlin et al. 2012: 189) and as 'just another translation of the underlying free-market and competition-based pillars on which the European Union is based' (Ibid.: 185).

Secondly, the very design of the Nabucco project also embodied the EU's market-liberal goals and established practice of projecting the internal energy 
market model abroad. The following statement of the EU co-ordinator for the Southern Corridor is exemplary:

The Commission must unambiguously assume jurisdiction over external natural gas pipelines, both those existing and those planned, and apply a single set of rules, including third party access, de-monopolization and investment protection and pursue gas company diversification; there should never be one company facing the European Union at the end of a pipe. (Van Aartsen 2009)

Accordingly, Nabucco followed what is known as a model of the 'merchant pipeline', meaning a pipeline built without a contract with gas producers and on the basis of unregulated gas prices (Finon 2011: 56). The Commission favoured the idea of a pipeline fully dedicated to European supplies (i.e., independent from the Turkish pipeline system), and with a legal regime guaranteeing non-discrimination and security of supply (Interview, EU official, April 2012). This is different from the 'ship-or-pay' model followed, for example, by the South Stream project, where companies from producer and consumer countries hold a majority stake in the new infrastructure, which is built on the basis of a long-term gas supply contract.

Thirdly, the energy diplomacy promoted by the Commission was also sui generis in its emphasis on multilateralism and transparency. The EU (via the Commission and the Presidency) acted as a facilitator of multilateral conferences involving Nabucco partners, and it brokered joint public declarations with interested countries. The multilateral IGA signed by the Nabucco transit countries in July 2009 was also published and approved by the parliaments of all signatory states. This contrasts with the standard practice of energy IGAs as bilateral agreements that are often dealt with higher levels of confidentiality.

Finally, Commission officials undertook the efforts of intertwining foreign and energy policy at the institutional level with scepticism (Interview, EU official, April 2014). Some moves towards greater co-ordination between the EU energy and foreign policy bureaucracies were indeed observed in the mid-2000s, for instance through the creation of an Energy Unit in the former Directorate-General (DG) Relex of the Commission, or the Network of Energy Security Correspondents (NESCO). However, the reorganization of the EU's foreign-policy system after the Lisbon Treaty led to a re-centralization of the external aspects of energy policy in DG Energy. The NESCO experience was short-lived, and no specific unit dedicated to energy matters was created within the EEAS. Staff from the Energy Unit of DG Relex were reintegrated into the Commission, either into DG Energy or DG Devco (Interview, EU official, May 2014). Since late 2013, there were attempts to create horizontal capacity for energy diplomacy within the Managing Directorate of Global and Multilateral Issues of the EEAS, although this has focused mainly on offering expertise and ensuring coherence across its geographical desks (Interview, member state diplomat, May 2014). 
This sort of energy diplomacy through energy governance has been seen by several actors in the field as one of the main obstacles to the realization of Nabucco. The Commission has been criticized for being 'too apolitical in dealing with the Southern Corridor' (Interview, member state diplomat, May 2014). The transit regime defended was also one of the main hurdles in the Nabucco process (Interview, EU official, April 2014). Turkey was reluctant to accept the proposed transit model, which was akin to the implementation of the EU energy acquis, meaning, for example, that the Turkish state-owned company BOTAŞ would lose control of transmission pipelines (Winrow 2009). This brings us to another source of resistance to EU-level energy diplomacy: the role of energy companies and governments.

\section{The business-state practices: the endurance of national energy diplomacy}

The EU's departure from its traditional market approach has also been constrained by the prevailing practices in the energy business sector. Energy companies have been defending their primary role and autonomy in the energy field by simultaneously clinging to market principles and yet maintaining close relations with state actors. In this vein, companies have generally opposed EU direct intervention in external diversification. For example, even companies such as the German RWE, a key company in the Nabucco consortium, did not support the potential large-scale provision of funds by the EU for infrastructure projects that would otherwise be financially unattractive (RWE [2011: 2-3]; see also Gasunie [2010: 2-3]). Echoing these concerns, even though the idea of directly funding pipeline construction work (and not only feasibility studies) had been endorsed by the Council in 2011, in practice this has continued to be opposed by several member states because this could distort markets or result in unfair competition (Interview, member state diplomat, May 2014).

Several companies have also explicitly criticized the Commission's support for the legal and commercial arrangement of the Caspian Development Corporation (CDC). The CDC was a single-purchasing mechanism that would allow gas demand to be aggregated across several member states in order to convince the Caspian producers to commit supplies to Europe (Devlin et al. 2012: 190). However, some companies referred to it as 'dangerous politicization of energy' (ENI 2011:3-4; E.ON 2010: 4) and 'a negative step that would damage rather than enhance the single European market' (BP 2010: 5). The association representing the European gas companies also described the CDC's block purchasing model as 'intrusive' (Eurogas 2009: 2) and potentially incompatible with EU competition law (Eurogas 2011: 5).

More generally, the EU's proposed measures to support diversification were also criticized by companies for going against long-established energy business practices. For example, the main partner of Gazprom in the South Stream project, ENI, expressed the following view to the Commission: 
Historically, energy investments have been underpinned by long-term contracts between European and extra-European companies. This model is a tested way to provide security of supply and timely infrastructure development. The EU should therefore keep supporting this process which does not require reinforced negotiating power of EU institutions. (ENI 2011: 3-4, emphasis in the original)

The dislike among important sectors of the business community, and even within DG Competition, of measures promoted by the EU to support Nabucco, such as the CDC, was also negatively perceived by potential suppliers (Interview, third country diplomat, May 2014).

The evolution and ultimate failure of the Nabucco negotiations are also an illustration of the relevance of the business-state link and practices. Instead of the initial Nabucco concept, Azerbaijan and Turkey eventually reached an agreement in December 2011 on the construction of the Trans-Anatolian Natural Gas Pipeline (TANAP) through Turkey, thus rendering the first section of the original Nabucco unnecessary. The Azeri state-owned company, SOCAR, would hold majority ownership of the project and Turkey, through its company BOTAŞ, would retain the right to negotiate discounted supplies for Turkish markets. Similarly, the later choice between possible pipeline routes to unite the future TANAP with the EU, namely the Nabucco West or the Trans-Adriatic Pipeline (TAP), also followed the rules of the game of national energy diplomacy. In July 2013, the companies operating the Shah Deniz 2 field in Azerbaijan opted for the TAP project, whose consortium was actually comprised of the main companies exploiting this field, and in the background of SOCAR's plans to acquire the Greek stateowned company DESFA. Overall, the initial idea of Nabucco, as a standalone gas corridor based on a multilateral non-discriminatory transit regime, was finally overtaken by several pipelines based on bilateral agreements between energy companies (often state-owned) and the authorities of the countries concerned.

\section{CONCLUSION}

Is there an emerging EU energy diplomacy? As argued in this article, the answer to this question depends on the analytical focus. In terms of policy discourse, the conclusion is certainly that the EU's approach to energy security has strongly embraced energy diplomacy ideas. This discursive change has also led to significant policy innovation, with the gradual adoption of a range of new instruments of EU-level energy diplomacy. However, a closer look at the policy practices on the ground reveals underlying continuity along the lines of the usual division of labour: EU-level external energy governance and national energy diplomacies. The result is therefore a hybrid mode of EU external energy policy characterized by new instruments of energy diplomacy, but largely interpreted and enacted through the lens of energy governance.

The constructivist institutionalist approach used to examine both discourse and practices has also contributed to explain this piecemeal change. On the 
one hand, following the expectations of DI on the conditions for successful policy ideas, this article has argued that the ascendancy of energy diplomacy in the policy discourse was facilitated by the appeal to normative ideas such as the obligation of solidarity, most prominently in communicative discourse. The analysis indicated that, although the co-ordinative discourse remained divided, it became progressively more difficult for state representatives to publicly defend the value of bilateralism in relations with suppliers, or to openly question the Nabucco pipeline. Despite the eventual failure of the EU's flagship project, the discursive shift was not inconsequential. As seen in more recent events, the changing discursive context has continued to provide a fertile ground for more ambitious proposals such as the 'Energy Union' concept, which proposes again further involvement by the Commission in IGAs, greater effort in external diversification, and the possibility to establish common-purchasing mechanisms (European Commission 2014). Significantly also, in July 2015 the EU Foreign Affairs Council adopted the first 'EU Energy Diplomacy Action Plan', further formalizing the support for these measures (Council of the EU 2015).

On the other hand, DI also predicted continuity in background ideational abilities. By looking at the level of policy practices, the analysis underlined the relevance of subtle forms of resistance and policy continuity that reside in the very way new instruments are implemented and practised, in turn determined by actors' dispositions and the tacitly accepted rules of the game in a given policy field. This was observed in the effort by Commission officials to bring new measures to support diversification in line with the EU's traditional market-liberal rules and procedures, as well as in the resistance by energy companies and governments to relinquish the established practices of national energy diplomacy in favour of an EU-level energy diplomacy. This finding is also consistent with the proposition that practices often tend toward reproduction, even when they are challenged. There is yet little elaboration by practice theorists as to how practices eventually change. Some authors have referred to the role of crises (Brueger and Gadinger 2014: 82), or also what Bourdieu called 'hysteresis effect' to describe the gap between the changing conditions in a field and actors' persistent habitus, which may eventually result in a 'creative reinvention' of practices (Bourdieu 1979, in Maton 2008: 60). More research is needed to determine whether a persistent gap between policy discourse and actual practices can also be seen as a form of hysteresis, and under which conditions this gap could precipitate a change in practices.

Finally, and more practically, this article has also pointed out the risks of the kind of third way of EU external energy policy emerging. On the one hand, the embracing of energy diplomacy discourse risks undermining the legitimacy of the EU's efforts to propagate its liberal energy market rules abroad (Kuzemko 2014), which continue to be an established policy under certain frameworks such as the Energy Community or the Energy Charter Treaty. On the other hand, as the Nabucco case has illustrated, external energy governance practices can also trump the EU's incipient energy diplomacy efforts. The immediate 
challenge is therefore not only to find a convincing narrative that justifies the emerging mixed model of EU external energy relations, but also to develop practices that can more flexibly adapt to different geopolitical and normative environments.

Biographical note: Anna Herranz-Surrallés is assistant professor in international relations at Maastricht University.

Address for correspondence: Anna Herranz-Surrallés, Faculty of Arts and Social Sciences, Grote Gracht 90-92, 6211 SZ, Maastricht, the Netherlands. email: Anna.Herranz@maastrichtuniversity.nl

\section{ACKNOWLEDGEMENTS}

I am grateful to David Buchan, Chad Damro, Johan Eriksson, Heidi Maurer, Michal Natorski, Julie Smith, Sophie Vanhoonacker, as well as two anonymous reviewers for their helpful comments and suggestions on earlier versions of this article. My thanks go also to the interviewees who generously shared their time and expertise. Any errors of substance or interpretation are, of course, mine alone. This research was supported by the Marie Curie Programme of the EU and the Catalan Agency for Management of University and Research Grants (AGAUR) in the framework of the Beatriu de Pinós Fellowship.

\section{SUPPLEMENTAL DATA AND RESEARCH MATERIALS}

Supplemental data for this article can be accessed on the Taylor \& Francis website, doi: 10.1080/13501763.2015.1083044.

\section{NOTE}

1 Some authors have also focused on the growing role of environmental concerns, most notably climate change, in the erosion of the market-liberal energy paradigm (Helm 2005; Kern et al. 2014; Kuzemko 2014). For the purposes of this article, environmental considerations are not analysed as a separate 'paradigm', but when relevant are included within the energy governance mode (see online supplemental material). This is because EU-level promotion of renewables and de-carbonization has consisted mainly of market-based instruments (Tosun and Solorio 2011: 7).

\section{REFERENCES}

Abbasov, F.G. (2014) 'EU's external energy governance: a multidimensional analysis of the southern gas corridor', Energy Policy 65: 23-36.

Adler, E. and Pouliot, V. (2011) 'International practices', International Theory 3(1): $1-36$.

Baev, P.K. and Overland, I. (2010) 'The South Stream versus Nabucco pipeline race: geopolitical and economic (ir)rationales and political stakes in megaprojects, International Affairs 86(5): 1075-90. 
Baumann, F. and Simmerl, G. (2011) Between Conflict and Convergence: The EU Member States and the Quest for a Common External Energy Policy, Munich: Center for Applied Policy Research.

Béland, D. (2009) 'Ideas, institutions, and policy change', Journal of European Public Policy 16(5): 701-18.

BP (2010) 'BP plc response to the European Commission DG Energy's public consultation on "Towards a new Energy Strategy for Europe 2011-2020", undated, available at https://ec.europa.eu/energy/en/consultations/towards-new-energystrategy-europe-2011-\%E2\%80\%93-2020 (accessed April 2012).

Buchan, D. (2009) Energy and Climate Change: Europe at the Crossroads, Oxford: Oxford University Press.

Bueger, C. and Gadinger, F. (2014) International Practice Theory: New Perspectives, Basingstoke: Palgrave MacMillan.

Correlijé, A. and Van der Linde, C. (2006) 'Energy supply security and geopolitics: a European perspective', Energy Policy 34(5): 532-43.

Council of the EU (2006a) 'A new energy policy for Europe', Council Document No. 5814/06, 6 February.

Council of the EU (2006b) 'A new energy policy for Europe', Council Document No. 6143/1/06 REV1, 17 February.

Council of the EU (2015) 'Council conclusions on energy diplomacy', Council Document No. 10995/15, 20 July.

Devlin, B., Momot, M. and Tourbach, L. (2012) 'The Southern Corridor - strategic aspects for the EU', in J. Vinois and P. Lowe (eds), The Security of Energy Supply in the European Union (EU Energy Law - Vol. VI), Deventer: Claeys \& Casteels, pp. 183-92.

Eikeland, P.O. (2011) 'The third internal energy market package: new power relations among member states, EU institutions and non-state actors?', Journal of Common Market Studies 49(2): 243-63.

ENI (2011) 'Response to European Commission's consultation on external energy relations', 7 March, available at https://ec.europa.eu/energy/en/consultations/ external-dimension-eu-energy-policy (accessed April 2012).

E.ON (2010) 'Public consultation. towards a new energy strategy for Europe 2011 2020', undated, available at https://ec.europa.eu/energy/en/consultations/ towards-new-energy-strategy-europe-2011-\%E2\%80\%93-2020 (accessed April 2012).

Escribano, G. Mahía, R. and Arce, R. (2011) 'The Europeanization of EU member state's energy security policies. Convergence patterns', in J.M. Marín-Quemada, J. García-Verdugo and G. Escribano (eds), Energy Security for the EU in the 21st Century, London: Routledge, pp. 2010-231.

Eurogas (2009) 'Caspian Development Corporation (CDC) Eurogas preliminary remarks', 30 July, available at http://www.eurogas.org/media-centre/positionspapers/ (accessed September 2015).

Eurogas (2011) 'The external energy policy of the European Union: an industry and market perspective from Eurogas', 31 May, available at http://www.eurogas.org/ uploads/media/Position_Paper_External_Energy_Policy_Paper_31.05.11.pdf (accessed September 2015).

European Commission (2014) 'European energy security strategy', COM(2014) 330 Final, 28 May.

European Commission and Secretary General/High Representative (2006) 'An external policy to serve Europe’s energy interests', Document No. S160/06, 15 June.

European Council (2006) 'Presidency Conclusions', Council Document No. 7775/1/ 06 REV 1, 23/24 March.

European Council (2011) 'Presidency Conclusions', Council Document No. EUCO 2/1/11 REV 1, 4 February. 
European Parliament (2001) 'Security of energy supply (debate)', 13 November, available at http://www.europarl.europa.eu/plenary/en/debates-video.html (accessed September 2015).

European Parliament (2003) 'Natural gas/petroleum product (debate)', 22 September, available at http://www.europarl.europa.eu/plenary/en/debates-video.html (accessed September 2015).

European Parliament (2007) 'Towards a common European foreign policy on energy' (debate), 25 September, available at http://www.europarl.europa.eu/ plenary/en/debates-video.html (accessed September 2015).

European Parliament (2010) 'Security of gas supply (debate)', 21 September, available at http://www.europarl.europa.eu/plenary/en/debates-video.html (accessed September 2015).

Finon, D. (2011) 'The EU foreign gas policy of transit corridors: autopsy of the stillborn Nabucco project', OPEC Energy Review 35(1): 47-69.

Gasunie (2010) 'Towards a new energy strategy for Europe 2011-2020', 30 July, available at https://ec.europa.eu/energy/en/consultations/towards-new-energystrategy-europe-2011-\%E2\%80\%93-2020 (accessed April 2012).

Goldthau, A. (2010) 'Energy diplomacy in trade and investment of oil and gas', in A. Goldthau and J.M. Witte (eds), Global Energy Governance: The New Rules of the Game, Washington DC: Brookings Institution Press, pp. 25-47.

Goldthau, A. and Sitter, N. (2014) 'A liberal actor in a realist world? The Commission and the external dimension of the single market for energy', Journal of European Public Policy 21(1): 1452-72.

Hall, P.A. (1993) 'Policy paradigms, social learning, and the state: the case of economic policymaking in Britain', Comparative Politics 25(3): 275-96.

Hay, C. (2006) 'Constructivist institutionalism', in A.W. Rhodes, S.A. Binder and B.A. Rockman (eds), The Oxford Handbook of Political Institutions, Oxford: Oxford University Press, pp. 56-74.

Helm, D. (2005) 'The assessment: the new energy paradigm', Oxford Review of Economic Policy 21(1): 1-18.

Herranz-Surrallés, A. (2012) 'Justifying enlargement in a multi-level polity: a discursive institutionalist analysis of the elites-public gap over EU enlargement', Journal of Common Market Studies 50(3): 385-402.

Kangas, O.E., Niemelä, M. and Varjonen, S. (2014) 'When and why do ideas matter? The influence of framing on opinion formation and policy change', European Political Science Review 6(1): 73-92.

Kern, F., Kuzemko, K. and Mitchell, C. (2014) 'Measuring and explaining policy paradigm change: the case of UK energy policy', Policy \& Politics 42(4): 513-30.

Kuzemko, K. (2014) 'Ideas, power and change: explaining EU-Russia energy relations', Journal of European Public Policy 21(1): 58-75.

Lavenex, S. (2004) 'EU external governance in "wider europe"', Journal of European Public Policy 11(4): 680-700.

Maton, K. (2008) 'Habitus', in M. Grenfell (ed.), Pierre Bourdieu: Key Concepts, Durham: Acumen, pp. 49-66.

Mayer, S. (2008) 'Path dependence and Commission activism in the evolution of the European Union's external energy policy', Journal of International Relations and Development 11(3): 251-78.

McGowan, F. (1989) 'The single energy market and energy policy: conflicting agendas?', Energy Policy 17(6): 547-53.

McGowan, R. (2011) 'Putting energy insecurity into historical context: European responses to the energy crises of the 1970s and 2000s', Geopolitics 16(3): 486511.

Natorski, M. and Herranz-Surrallés, A. (2008) 'Securitizing moves to nowhere? The framing of the European Union's energy policy', Journal of Contemporary European Research 4(2): 71-89. 
Neumann, I.B. (2002) 'Returning practice to the linguistic turn: the case of diplomacy', Millennium Journal of International Relations 31(3): 627-51.

Padgett, S. (2009) 'External European Union governance in energy: full research report', ESRC End of Award Report No. RES-000-22-2562, Swindon: ESRC.

Prange-Gstöhl, H. (2009) 'Enlarging the EU's internal energy market: why would third countries accept EU rule export?', Energy Policy 37: 5296-303.

Roth, M. (2011) 'Poland as a policy entrepreneur in European external energy policy: towards greater energy solidarity vis-à-vis Russia?', Geopolitics 16(3): 600-25.

RWE (2011) 'Answer to the public consultation on the external dimension of EU energy policy', undated, available at https://ec.europa.eu/energy/en/ consultations/external-dimension-eu-energy-policy (laccessed April 2012).

Schmidt, V.A. (2006) Democracy in Europe: The EU and National Polities, Oxford: Oxford University Press.

Schmidt, V.A. (2008) 'Discursive institutionalism: the explanatory power of ideas and discourse', Annual Review of Political Science 11: 303-26.

Schmidt, V.A. (2010) 'Taking ideas and discourse seriously: explaining change through discursive institutionalisms the fourth "new institutionalism", European Political Science Review 2(1): 1-25.

Schmidt-Felzmann, A. (2011) 'EU member states' energy relations with Russia: conflicting approaches to securing natural gas supplies', Geopolitics 16(3): $574-99$.

Socor, V. (2009) 'Chancellor Merkel's letter perturbs EU's energy debate', Eurasia Daily Monitor 6(23), available at: http://www.jamestown.org (accessed September 2015).

Streeck, W. and Thelen, K. (2005) 'Introduction: institutional change in advanced political economies', in W. Streeck and K. Thelen (eds), Beyond Continuity: Institutional Change in Advanced Political Economies, Oxford: Oxford University Press, pp. 1-39.

Surel, Y. (2000) 'The role of cognitive and normative frames in policy-making', Journal of European Public Policy 7(4): 495-512.

Tosun, J. and Solorio, I. (2011) 'Exploring the energy-environment relationship in the EU: perspectives and challenges for theorizing and empirical analysis', European Integration online Papers 15(7), available at http://eiop.or.at/eiop/texte/ 2011-007a.htm (accessed September 2015).

Umbach, F. (2010) 'Global energy security and the implications for the EU', Energy Policy 38(3): 1229-40.

Van Aartsen, J. (2009) 'Activity report. September 2007-February 2009', 4 February, available at: https://www.rijksoverheid.nl/ (accessed September 2015).

Winrow, G.M. (2009) 'Problems and prospects for the 'Fourth Corridor': the positions and role of Turkey on gas transit to Europe', OIES NG No. 30, Oxford: Oxford Institute for Energy Studies.

Youngs, R. (2011) 'Foreign policy and energy security: markets, pipelines and politics', in J.S. Duffield and V.L. Birchfield (eds), Toward a Common European Union Energy Policy, New York: Palgrave Macmillan, pp. 41-60. 